\title{
Global imaginaries: re-thinking possibilities for GCE
}

\begin{abstract}
Global Citizenship Education (GCE) is often seen as the best response to contemporary global humanitarian, social and political challenges. Yet despite this newfound popularity, GCE remains a contentious and widely debated concept. Critiques have stressed the abstract and elusive nature of the notion, its lack of concrete legal framework as well as its bias towards a Western, neoliberal and consumerist agenda, which is not devoid of colonial undertones. This paper seeks to address this latter tension by examining GCE through the lens of global imaginaries, which looks at imagination as a new social practice, capable of generating transformation and change. Building on the work of Paul Ricoeur, in particular the ideas of utopia, imagination and social imaginaries, this paper aims to offer new conceptualisations of GCE around the notion of global imaginaries, in an attempt to overcome the dichotomies that tend to underpin the concept.
\end{abstract}

Keywords: Global Citizenship Education, Ricoeur, global imaginaries

\section{Zusammenfassung}

Global Citizenship Education (GCE) wird oft als die beste Antwort auf die heutigen globalen humanitären, sozialen und politischen Herausforderungen gesehen. Doch trotz dieser neu gewonnenen Popularität bleibt GCE ein umstrittenes und breit diskutiertes Konzept. Kritiker haben die abstrakte und schwer fassbare Bedeutung des Begriffs betont, das Fehlen eines konkreten rechtlichen Rahmens sowie die Vorliebe für eine westliche, neoliberale und konsumorientierte Agenda, die nicht frei von kolonialen Akzenten ist. Der vorliegende Beitrag versucht, diese letztere Spannung zu thematisieren: GCE wird vor dem Hintergrund der globalen Imaginationen untersucht, die - als eine neue soziale Praxis betrachtet - in der Lage ist, Transformation und Veränderung zu erzeugen. Aufbauend auf der Arbeit von Paul Ricoeur - insbesondere den Ideen von Utopie, Imagination und sozialen Imaginären - zielt dieser Beitrag darauf ab, neue Konzeptualisierungen von GCE um den Be- griff des globalen Imaginären herum anzubieten: Dabei wird der Versuch unternommen, Dichotomien zu überwinden, die dem Konzept zugrundeliegen.

Schlüsselwörter: Global Citizenship Education, Ricoeur, globale Imaginationen

\section{Global Citizenship Education: utopia and imagination}

There is an assumption that, in the $21^{\text {st }}$ century, global citizenship is a natural response to the world we live in. As a result of globalisation, communication, mobility and the erosion of national boundaries, we are more interconnected than ever before. At the same time, issues linked to conflict, human migration and State security have taken unprecedented forms across the globe. Recent examples include the humanitarian and refugee crisis in the Middle East and Europe, the Brexit vote in June 2016 or the immigration ban in the US in 2017 and 2018.

The questions of how to live together in a world that is becoming increasingly interconnected is now closely linked to questions of how to co-exist in times of economic crisis and austerity, increased fear, securitization and conflict. Global Citizenship Education (GCE) has been put forward as a response to these social, political and humanitarian challenges. It has come to occupy an important place on the international agenda, identified as a key strategic area for UNESCO's 2014-2021 education sector and explicitly referenced in the 2015 UN Sustainable Development Goals (Target 4.7).

Yet despite its newfound popularity, GCE remains a contentious concept. Critiques have stressed the abstract and elusive nature of the notion, its lack of concrete legal framework (Davies, 2006), as well as its bias towards a Western, neoliberal and consumerist agenda, which is not devoid of colonial undertones (Marshall, 2011; Andreotti, 2014). This paper seeks to address the apparent tension between perceived dominant (alienating) and alternative (emancipatory) conceptions of GCE. Building on the work of Paul Ricoeur, in partic- 
ular the ideas of utopia, imagination and social imaginaries, this paper offers new conceptualisations of GCE around the notion of global imaginaries, in an attempt to overcome the dichotomies that underpin the concept.

\section{What is global citizenship and why do we need it?}

Although present in policy and educational discourse for over 60 years, Global Citizenship has gained momentum since the early 2000s, in particular in the realm of education (Davies, 2006; Iva, Stephens \& Nandini, 2012). Most commonly seen as a response to increased globalisation, new forms of mobility and the erosion of national boundaries, GCE has benefited from both intensified academic attention and recent integration within national and international policy discourse and associated educational initiatives. Global citizenship has multiple definitions which vary across different areas, reflected in the different practices, agendas and actors of global citizenship (Marshall, 2011).

Unsurprisingly, in scholarly work, the concept of global citizenship holds different meanings across different contexts and disciplinary or academic fields, which reflect the multiple perspectives and economic or political agendas that underpin this notion. Although the concept has gained increased presence in academic literature from a range of disciplinary backgrounds, there is no unified definition of the term. Different views in current academic literature reflect dissentions around the notion of "global" and "globalisation" themselves, a contentious notion in academia, often criticised for being poorly theorised, despite the vast field of academic literature on the topic (Appadurai, 1996; Burns, 2008; Blommaert, 2010; Kamola, 2014; Steger, 2009). The lack of consensus around these notions is reflected in the dichotomies that frame debates around globalisation: in particular, the tension between emancipatory and alienating forms of globalisation (Beck, 2004; Burns, 2008; Welply, 2015, p. 231). Global citizenship and its place in education are caught in similar tensions.

The centrality of education for developing global citizenship emerged as a result of competing agendas, which range from training globally competitive graduates for the labour market to equipping young people with the capacity to address world challenges, present and future, and the "realisation that schools are always part of global networks and flows of information, goods and people" (Marshall, 2011, p. 213). Disagreements around the notion of Global Citizenship Education reflect controversies over the impact of globalisation and the concept of global citizenship itself.

\section{For or against global citizenship education? - overcoming dichotomies}

This points to a central criticism of the role of global citizenship education: does GCE allow students to engage and challenge global inequalities or does it tend to favour the development of global consumers (Osler, 2008; Roth, 2007; Beck, 2004)? This question underpins the argument that GCE has been instrumentalised to support a neoliberal, consumerist agenda that privileges certain groups over others in the pur- suit of political and economic goals and raising standards in schools (Marshall, 2011; Andreotti, 2014). In this view, the so-called "international" conceptions of GCE are seen to in fact mask ethnocentric values of the West or the Global North, which negate the realities of migrant populations from the Global South and the limited choices that are available to them in terms of citizenship, including the dispossession of citizenship faced by asylum seekers and refugees. This critique of the normative and universal assumptions of global citizenship has led to an increasing number of scholars calling for the decolonisation of global citizenship education and its re-invention (Andreotti, 2014; Marshall, 2011; Todd, 2008; Rizvi, 2008, 2009). This shift entails a process of questioning and critical reflection on assumptions of universality or of a shared global interconnectedness which overlooks power differentials and global hierarchies inherited from colonial history. Andreotti (2014) differentiates between "soft" global citizenship, which adopts a deficit model to think about global inequalities from a more "critical" global citizenship which addresses structural inequalities, unequal power relations, injustices and symbolically violent systems, to understand disparities in terms of access, wealth and resources across the globe. This entails rethinking taken-for-granted notions of universality, stability (which leads to the avoidance of conflict and complexity), consensus (which leads to the elimination of difference) and fixed identities. Suggested starting points to achieve this are "learning to unlearn" (ibid.); engaging with difficult and controversial issues (Davies, 2006); recognising conflict and crises (Todd, 2008) and acknowledging the historical, cultural and political values attached to our representations of the global, in order to question the "hegemonic social imaginaries of globalisation” (Rizvi, 2008, 2009, p. 265).

It is not possible in this space to fully engage with the academic debates around global citizenship education, but what emerges from the literature is a set of polarised debates around the different goals of global citizenship education and its implementation in practice. There are multiple conceptions of global citizenship and approaches to global citizenship education, inscribed in sometimes contradictory discourses and with contrasting agendas. Whilst a postcolonial lens and critical approach to global citizenship (Andreotti, 2014) allows us to question some of the more hegemonic and neo-colonial forms of GCE, questions remain around who defines citizenship. Who teaches it? How is it taught? How will it shape learning and schools? What about Higher Education experiences? Finally, there remains the question of how we reconcile the ideals and ethos of global citizenship education with the realities of education today, with testing, its lower place in the curriculum, a different global agenda in terms of competition and risk taking.

Absent from many of the critical debates around global citizenship education is the notion of emancipation as a corollary to domination (Boltanksi, Fraser \& Corcuff, 2014). Whilst the limitations and challenges of GCE are well mapped in the literature, its possibilities beyond a neoliberal Western agenda remain rather vague. This paper seeks to address these limitations by examining GCE through the lens of global imaginaries, which looks at imagination as a new social 
practice, capable of generation transformation and change (Appadurai, 1996).

Whilst imagination might seem to echo the critique of global citizenship as a "mere fiction" (Davies, 2006), it has also become an emergent theme in scholarly literature which engages with globalisation. Recognising imagination's function as a social practice helps shift the focus towards a recognition of the more cultural and symbolic aspects of globalisation (Appadurai, 1996; Blommaert, 2008, p. 439). This includes new, transnational and multiple forms of affiliation (Banks, 2014; Appadurai, 1996) which call for reframing existing boundaries and categories (Welply, 2015). As such, imagination gives a new role to globalisation, allowing minoritized groups and individuals to negotiate global cultural trends (Appadurai, 1996; Burns, 2008), critically engage with globalisation (Delanty, 2009 , p. 250) or cultivate "shared humanity" or cosmopolitanism through "narrative" or "sympathetic" imagination, as a foundation for global citizenship education (Nussbaum, 1998, 2002; Appiah, 2006, 2017). Here, imagination is not a mere fantasy, nor is it uncritical. As a social practice or critical tool, it is what allows people to engage critically with different possibilities at the global level, beyond a sole economic reading of globalisation. The function of imagination is also put forward as a form of engagement in pluralistic, diverse and global societies, with implications for thinking about belonging and citizenship, the local and the global (Arendt, 1978; Greene, 1995, 2009).

As a corollary to the role of imagination in understanding the global, the concept of "global imaginary" has been suggested as way of theorising the symbolic and cultural aspects of globalisation (Taylor, 2004; Steger, 2009; Kamola, 2014) and, more specifically, as a foundation for critically engaging with uncritical ideas of global citizenship (Stein, Andreotti \& Suša, 2016; Stein \& Andreotti, 2016). Building on the concepts of social imaginary (Steger, 2009; Taylor, 2004) and cosmopolitanism (Delanty, 2009; Nussbaum, 2002), the notion of global imaginary tends to remain poorly theorised (Kamola, 2014). Nevertheless, Stein et al. offer a pertinent critique of the assumptions around internationalisation and development through the lens of global imaginary, which helps to reveal the "dual processes of European modernity and colonialism" at play in dominant discourses of the global (2016, p. 4). Expanding on Taylor's notion of social imaginaries (Taylor, 2004; Castoriadis, 1987) the authors show how a "modern/colonial global imaginary", which emerged around the European Renaissance came to dominate perspectives on the world and legitimise a "Western/European perspective as a universal blueprint for global designs" (Stein \& Andreotti, 2016, p. 164).

"Since its beginnings, this [global] imaginary has also been the object of resistance, but because imaginaries circumscribe both the questions that are deemed worth asking and the answers that are deemed legitimate, alternative imaginaries (global or otherwise) are often repressed, co-opted or deemed unintelligible or illegitimate" (ibid., p. 174)

This global imaginary delegitimises alternative imaginaries, which are met "with disbelief or denial" (Stein, Andreotti \&
Suša, 2016, p. 4), thus maintaining belief systems and normative frameworks that place the West as dominant and at the centre of global development and human progress. This global imaginary is historically inscribed within institutionalised racial/colonial inequalities and power relations, underpinned by violence and economic exploitation. Although this global imaginary has changed throughout history, the inequalities and unitary forms of meaning-making and knowledge production upon which it is premised remain fairly unchanged. In its latest iteration, this global imaginary takes the form of the "neoliberal present" (Stein \& Andreotti, 2016). Although alternative social imaginaries have been put forward, which aim to promote non-capitalist approaches and an emphasis on local knowledge and a plurality of perspectives, these alternatives remain marginalised and de-legitimised by the dominant global imaginary. The above constructs a clear binary opposition between dominant and alternative global imaginaries, which at times seems difficult to overcome.

Whilst, in the above, the notion of the global imaginary offers a powerful tool for questioning the normative assumptions of global citizenship education and the internationalisation of higher education, the concept remains only partially theorised, which makes it difficult to dissociate between the idea of "global imaginary" and the notion of "discourse". As such, it is not always clear what the notion of global imaginary has to offer as an analytical tool beyond the notion of discourse or of dominant paradigms, beliefs and values which hold a normative and legitimising function and disqualify alternative possibilities. The notion of global imaginary here is constructed as a set of linear, homogenous, static and uncontested spaces, which create a binary opposition between the dominant, Western/European modern/colonial global imaginary and a postcolonial critique of this imaginary. Whilst this offers a powerful critique, it is difficult to see beyond a dichotomous construction of social imaginaries of the global. When it comes to thinking about global citizenship education, this means that it remains caught between fundamental binary oppositions: soft versus critical and dominant (alienating) global imaginary versus alternative (emancipating) global imaginary.

These binaries help engage critically with dominant discourses and implicit ethnocentric conceptions of global citizenship education. However, they run the risk of getting caught in a solely critical lens, which then becomes dissociated from possibilities of emancipation or change (Boltanski, Fraser \& Corcuff, 2014). This posits Global Citizenship Education in an ambiguous and contradictory place: both critiqued as an instrument of neo-liberal domination and hailed as the way to overcome global inequalities, injustice and conflict. This article argues that these two dimensions need not be solely in contradiction with each other. To help address this tension, we turn to the Ricoeur's hermeneutic approach, in particular his work on social imaginary, at the heart of a dialectic between ideology and utopia $(1984,1986)$.

\section{Global imaginaries as ideology and utopia}

Paul Ricoeur's notion of social imaginary can be understood as the set of stories that are held by society. These stories operate in society through people's everyday life, often subconsciously, 
to produce "collective narrative stories we tell ourselves in order to explain ourselves to ourselves and to others" (Kearney, 2004, p. 75). Thus, social imaginaries are what form social identity, developed through collective narratives, symbols, ideals and norms, through which individuals and groups recognise themselves. These groups can be a nation, a minority group, a diasporic or transnational group with a sense of shared identity. Social imaginaries are at the centre of a dialectic of ideology and utopia. Ideology is what provides the symbolic limits of what is possible, whilst utopia opens up to alternative future possibilities (Langdridge, 2006, p. 646). Ricoeur's dialectic of ideology and utopia, situates ideology as fundamental to the social bond, and in that sense no one group can situate itself outside of ideology. Building on this premise, Ricoeur recognises the hidden role of ideology, but refuses to limit it to the idea of "false consciousness", which has underpinned the majority of social theory in the 20th century (the work of Freud and Marx, for example). For Ricoeur, ideology holds both a negative and positive dimension, through its utopian function $(1984,1986)$. In Ricoeur's view, social action is symbolically mediated, thus shaping an "ideological imagination" (Kearney, 2004, p. 85). In that sense, ideology confers consistency and permanence to a social group, through a stable imaginary which the group projects of itself. Whilst ideology enforces integration, legitimation and domination; utopia, by questioning the legitimate social reality, puts power in question and opens up new possibilities (Ricoeur, 1986; Mannheim, 1936).

Whilst ideology and utopia might, at first glance, appear to be polar opposites, they are in fact "held together in a dialectical relationship, through imagination" (Welply, 2015, p. 432). Positioned as two antagonistic poles of the collective imaginary, ideology and utopia participate in the creation of a "double imaginary" (1984, p. 53, author's translation) which together form social and cultural imaginaries (ibid). In this perspective, the concept of social imaginary is understood as the stories that shape the symbolic realm of society. It "rests on the tension between the integrative function of ideology and the subversive function of utopia" (Ricoeur, 1984, p. 63; Welply, 2015, p. 433). This dialectic underpins the concept of social imaginary, defined as "the interplay of ideals, images, ideologies and utopias informing our political unconscious' (Kearney 2004 , p. 75)", central to Ricoeur's notion of ideology and utopia. This view attempts to overcome the opposition between institution and imagination through an "institutionalising imagination" (Abel \& Porée, 2008, p. 63). Whilst utopia, "through its fundamental function of contestation and projection of a radical elsewhere" ${ }^{2}$ (Ricoeur, 1984, p. 63) allows one to question ideologies critically, ideology "cures utopia from the madness in which it constantly risks sinking"3 (Ricoeur, 1984, p. 63-64) by "providing a historical community with the equivalent of a narrative identity" (ibid.). Social imaginary is thus 'a reflexion on imagination and its practical and political function' (Abel \& Porée, 2008, p. 65).

Whilst Ricoeur recognises the existence of the negative dimension of ideology as 'false consciouness' and the necessity to analyse it critically, he calls for "resisting the reduction of the social imaginary to ideological distortion [and] argues instead for an affirmation of its utopian potentials" (Kearney, 2004, p. 76). To do this, "hermeneutics of doubt may be preserved and also supplemented by a hermeneutics of invention" (ibid., p. 78), which "seek to discriminate between falsifying and emancipating modes of symbolization” (ibid., p. 76). According to Ricoeur, "the second function of hermeneutic understanding is the utopian function which does not focus on the origin of symbols (the archeological approach) but rather on the horizon and aspirations of symbols (future)" (ibid., p. 84). Hermeneutic interpretation functions as a "creative interplay" between the claims of ideology and utopia (ibid.). In this hermeneutic interpretation, "the social imaginary has a temporal dimension: ideology functions as integration and "symbolic construction of social memory" (Ricoeur, 1984, p. 57) whilst utopia opens up to alternative and future possibilities (Ricoeur, 1984; Langdridge, 2006; Welply, 2015, p. 433).

The concept of global imaginaries developed in this paper is framed by Ricoeur's notion of social imaginaries as a dialectic between ideology and utopia, with imagination at the heart of this dialectic. In this view

"The symbolic and material representations of the glo-
bal, but also the national and the local, are articulated
through narratives to create global imaginaries, inscribed
in memory and in future horizons. Global imaginaries
are both utopian (across spaces) and uchronic (across
time)" (Welply, 2015, p. 433).

This perspective helps address some of the limitations of globalisation theories and conceptualisations of global imaginaries, in particular their binary representations. The notion of global imaginaries helps overcome the tension of the global versus the local, by recognising their mutually constitutive nature. The global only ever happens and is interpreted at a local level, which participates in its symbolic meaning-making. The concept of global imaginaries, through a hermeneutic approach, also allows the analysis to overcome the dichotomy between alienating and emancipatory perspectives and discourses of the global (Appadurai, 1996; Burns, 2008; Stein \& Andreotti, 2016). The ways in which this divide can be transcended is the central focus on this paper.

Ricoeur's notion of social imaginary, caught between ideology and utopia, allows us to conceive of global imaginaries that engage with collective narratives and symbolic representations and help us overcome a single focus on critique only (here, a critique of the dominant Western/colonial global imaginary or neoliberal approach to global citizenship education), or on emancipation only (alternative global imaginaries, delegitimised by dominant "global" discourses) (Stein \& Andreotti, 2016; Andreotti, 2014). This dialectic between ideology and utopia allows us to think of global citizenship education as situated at the centre of divergent or contradictory global imaginaries. However, rather than discrediting it, recognising these contradictions as constitutive of these global imaginaries, and a necessary tension for their existence, can help reframe GCE outside of these binary representations. The key role given to imagination can help think of the potential of global citizenship education, whilst acknowledging the risk of domination of certain symbolic and material interpretations within it. The temporal dimension of Ricoeur's notion of social imaginary, through the notions of promise and utopia, stresses the impor- 
tance of time in thinking about global citizenship education, and the need to recognise its temporal inscription within past, present and future. This temporal dimension allows us to consider both forms of historical and symbolic alienation and violence embedded within the notion of global citizenship and its transformative potential, thus acknowledging the capacity for action and change.

If we acknowledge the dialectic between ideology and utopia as fundamental to global imaginaries, this opens up a new understanding of global citizenship education which can escape the polarisation between ideas of Western, colonial domination and an alternative, decolonising critique of global citizenship education. The possibility for change and transformation is not to be sought only "outside" of dominant imaginaries of the global or GCE, but rather transformation is intrinsic to the ideologies themselves and the tensions upon which they rest, their utopian corollary. In this view, young people need to have both the tools to critically engage with dominant ideologies whilst participating into actual change. This does not mean that we fall into "positivist ideologization" (Begag, 1997) in which the emancipatory aspect of global citizenship education masks forms of domination, preventing young people from being political subjects who can critically engage with hegemonic discourses that are neoliberal and Western. Nor does it tie young people into what Berlant terms "cruel optimism" (2011) at the expense of action, dispossessing them of the capacity to be political subjects (Arendt, 1978). However, it avoids the risk of focusing on critique only, and opens up possibilities for emancipation (Boltanksi, Fraser \& Corcuff, 2014).

If we take global imaginaries to rest on a dialectic between ideology and utopia, then the function of global citizenship education can be defined as transcending the divides that underpin it. It can embrace both skills and knowledge, focus on the Self and Other, the local and the global, and educate young people to develop a critique of domination as well as emancipation. This can help overcome dichotomies when thinking about the principles of global citizenship education, whilst maintaining a critical engagement with dominant discourses. As, such, the nurturing and development of global imaginaries allows multiple possibilities for interconnection and a recognition of our "shared humanity" (Nussbaum, 1998) and shared responsibility for the planet. These can help transcend divisions and negative representations of the Other. Examples in practice are the formation of points of imaginary encounters in the past, present or future, between young people or children who view themselves as global citizens; or children's spontaneous joint-cultural creation (artistic, literary or musical) which transcends traditional categories of difference and allows a re-negotiation of Otherness across set boundaries (for further discussion, see Welply, 2015).

If global citizenship education can at the same time nurture and critically engage with global imaginaries, recognising their utopian function, and the capacity to create an "elsewise and an elsewhere", it carries a transformative potential that allows a questioning and re-negotiation of global ideologies whilst engaging with current global challenges and ideas of shared humanity. Imagined connections, re-framed identities that can overcome constructions of Otherness or forms of sep- aration and categorisation create new possibilities for action. As such, global imaginaries transcend a "mere fiction" and allow global citizenship to be more than an ideal, situated at the cusp of knowledge and action. It opens up understandings of the world that engage with old and new conceptions, in a dialectic of permanence (idem) and change (ipse) (Ricoeur, 1992), and as such create the space and possibilities for change. It also allows global citizenship education to be recognised within all its complexities and inconsistencies, which can help overcome the sometimes-paralysing polarisation of debates within which GCE has been caught. This dialectal relationship allows the uchronic function of global imaginaries to critically question the relationship of GCE to past/present/future, the historical and postcolonial legacy and neoliberal discourse, whilst acknowledging the possibilities of new futures through action. This engagement is also utopian, offering multiple spaces, at multiple levels. Thus, global citizenship education needs to be located within the interplay of local, national and global spaces and representations, which are connected in mutually constitutive ways.

This new framing of GCE rests upon the role of imagination as a social practice. It creates alternative possibilities that allow discrimination and divisions to be overcome (Greene, 1995). Global imaginaries hold implications for thinking about the notion of citizenship itself, where it takes place, how it is conceptualised and how it comes into being. Fostering global imaginaries that are both critical but allow young people to transcend national boundaries in thinking about their place in the world will allow them to embrace the idea of "shared humanity" (Nussbaum, 1998) and avoid the pitfalls of current nationalistic revival/discourse and thickening/re-nationalising of citizenship. It also allows a critical questioning of the new global, consumer-oriented neoliberal citizen, which tends to essentialise the Other, and is far from accessible to all (Beck, 2004; Burns, 2008). This allows young people to not only reflect upon and critique dominant global discourses, but also to become active and engaged political subjects (Arendt, 1978; Welply, 2019).

In fostering global imaginaries, the tensions between the emancipatory and alienating possibilities they contain, and as such, the tensions that underpin global citizenship and the way it is developed through education, are not erased. Rather, they exist themselves within the dialectical relationship of ideology and utopia, from which we cannot escape (Ricoeur, 1986 , p. 312). This allows global imaginaries and global citizenship to be conceptualised as both emancipating and alienating, offering creative and liberating possibilities whilst at the same time being critical of its dominant and restrictive functions. One need not exclude the other but instead offer new challenges to be addressed by GCE, beyond binary oppositions and polarised debates.

This raises particular questions for GCE at all levels of education. In particular, how can educational systems, which are still strongly inscribed within national beliefs and value, encourage the empowering possibilities offered by global imaginaries whilst at the same time fostering tools that allow a critical examination of global issues and representations? (Welply, 2015, p. 449). In this paper I suggest that GCE needs to foster a deeper engagement with students' global represen- 
tations that embraces both a critical engagement with global discourses and a creative engagement with the transformative possibilities of global citizenship.

Global imaginaries allow us to situate individuals and institutions within the complexity of global imaginaries and their different (non-exclusive) dimensions and recognise the multiple processes of engagement with the global, raising question for global citizenship education. A focus on global imaginaries, allows global citizenship education to include both its material and symbolic forms. It allows global citizenship education to engage with a renewal of social critique within the realities of globalisation, namely what possibilities are imagined/ created for global citizens and how can they be actuated socially and politically?

\section{Conclusion}

To conclude, the concept of global imaginaries offers a hermeneutic analysis of the idea of common (sustainable) belonging, transformation and change in relation to dominant ideologies of the global. This allows us to transcend the dichotomous representation between a dominant Western, neoliberal global imaginary and alternative possibilities. It also allows us to think more deeply and critically about the aims of GCE and what it means for students, teachers or educationalists: does embracing critiques of hegemonic discourse of the global preclude taking part in the global economy? Are there spaces for dialogue between conflicting global imaginaries? If so, where are the possibilities for change? How can the material or physical practices of GCE be reconciled, if at all, with wider symbolic aspirations? By allowing students, teachers and educators to address such questions, this approach to global imaginaries can help them engage with the complexities of the symbolic and material manifestations of the global, and their sometimes contradictory nature. Global aspirations of mobility and interconnectedness might at times be at odds with immediate, more local or national experiences. Giving students and teachers the tools to overcome what at first glance might seem like unreconcilable tensions can help open up new spaces for dialogue and for transformative action. This allows individuals to reconnect to the collective, and become engaged political subjects rather than mere consumer-citizens (Arendt, 1978; Welply, 2019). Recognising the sometimes conflicting experiences of individuals themselves, caught also at the cusp of the dialectic between ideology and utopia, or permanence and change, can also help students or teachers develop the necessary critical tools to reflect on global challenges, recognise shared responsibility for the planet and our interconnectedness (ideologie(s), whilst providing them with the aspirations and hope to act towards change (utopia), creating a "politics of hope". For this, I suggest six pillars for Global Citizenship Education that are, in my view, central to fostering critical, inclusive and emancipatory global imaginaries: (1) Literacy (textual, visual, numerical, digital), (2) Awareness and reflection (individual and collective), (3) Recognition (of self and others), (4) Transcendence (inter-, in between, crossing boundaries, (5) Resilience (personal and political) and (6) Hope (as "politics for hope" and capacity for action through a herme- neutic of imagination). Whilst there is not the space to discuss each pillar in detail, they provide the foundations for thinking of news forms of Global Citizenship Education that are both critical and transformative.

Global Citizenship Education necessitates new global analytical frameworks that allow it to overcome the dichotomies in which it has been caught. Ricoeur's notion of social imaginaries helps develop a concept of global imaginary that underpins a new form of social critique through the development of critical skills whilst at the same maintaining the potential for change, transformation and imagining new possibilities. At a time of evidence-driven educational policy, large scale international comparisons and global league tables, with an overwhelming emphasis on "what works?", this approach might seem rather idealistic and disconnected from the educational realities of our time. It is precisely within these times that we strongly need new horizons of possibilities and re-imagined forms of education that allow alternative forms of engagement with local and global challenges, transformation and the capacity for action.

\section{Annotations}

1 Author's translation 'Imagination institutionalisante'(Abel \& Porée, 2008, p. 63).

2 Author's translation 'L'utopie dans sa function fondamentale de contestation de projection dans un ailleurs radical' (Ricoeur, 1984, p. 63).

3 Author's translation 'Pour guérir l'utopie de la follie où elle risque sans cesse de sombrer' (Ricoeur, 1984, p. 63).

4 Author's translation 'Sa capacité de donner a une communauté historique l'équivalent de ce que nous appelions hier une identité narrative' (Ricoeur, 1984, p. 64).

\section{References}

Andreotti, V. (2014). Soft versus critical global citizenship education. In Development education in policy and practice (p. 21-31). London: Palgrave Macmillan. https://doi.org/10.1057/9781137324665_2

Appadurai, A. (1996). Modernity at large: cultural dimensions of globalization. Minneapolis: University of Minnesota Press.

Appiah, K. A. (2006). Cosmopolitanism. New York: Penguin.

Arendt, H. (1978). The Life of the mind. New York: Harcourt Brace.

Banks, J. A. (2014). Diversity, group identity, and citizenship education in a global age. Journal of Education, 194(3), 1-12. https://doi.org/10.1177/0022057414194 00302

Beck, U. (2004). Cosmopolitical realism: On the distinction between cosmopolitanism in philosophy and the social sciences. Global networks, 4(2), 131-156. https:// doi.org/10.1111/j.1471-0374.2004.00084.x

Begag, A. (1997). Trafic De Mots En Banlieue. Du "Nique ta Mère” Au "Plaît-Il?". Migrants Formation, 108, 30-37.

Berlant, L. G. (2011). Cruel optimism. Durham, NC: Duke University Press. https:// doi.org/10.1215/9780822394716

Blommaert, J. (2008). Bernstein and poetics revisited: Voice, globalization and education.Discourse\&Society, 19(4),425-451.https://doi.org/10.1177/0957926508 089938

Blommaert, J. (2010). The sociolinguistics of globalization. Cambridge: Cambridge University Press. https://doi.org/10.1017/CBO9780511845307

Boltanski, L., Fraser, N., \& Corcuff, P. (2014). Domination et émancipation: Pour un renouveau de la critique sociale. Lyon: Presses universitaires de Lyon.

Burns, K. (2008). (re)Imagining the global, rethinking gender in education. Discourse: studies in the cultural politics of education, 29(3), 343-357. https://doi. org/10.1080/01596300802259111

Castoriadis, C. (1987). The imaginary institution of society. Cambridge, MA: MIT Press. 
Davies, L. (2006). Global citizenship: abstraction or framework for action? Educational review, 58(1), 5-25. https://doi.org/10.1080/00131910500352523

Delanty, G. (2009). The cosmopolitan imagination: The renewal of critical social theory. Cambridge: Cambridge University Press. https://doi.org/10.1017/CBO978051 1642227

Greene, M. (1995). Releasing the imagination: Essays on education, the arts, and social change. Jossey-Bass. https://doi.org/10.1057/9780230100893_8

Greene, M. (2009). Teaching as possibility: A light in dark times. In Critical pedagogy in uncertain times (p. 137-149). New York: Palgrave Macmillan.

Kamola, I. (2014). US universities and the production of the global imaginary. The British Journal of Politics and International Relations, 16(3), 515-533. https://doi. org/10.1111/j.1467-856X.2012.00540.x

Kearney, R. (2004). On Paul Ricoeur. The Owl of Minerva. Aldershot: Ashgate.

Langdridge, D. (2006). Ideology and Utopia: Social Psychology and the Social Imaginary of Paul Ricoeur. Theory Psychology, 16(5), 641-659.

Mannheim, K. (1936). Ideology and Utopia. London: Routledge

Marshall, H. (2011). ,Instrumentalism, ideals and imaginaries: theorising the contested space of global citizenship education in schools 'Globalisation. Societies and Education, 9(3-4), 411-426. https://doi.org/10.1080/14767724.2011.605325

Nussbaum, M. C. (1998). Cultivating humanity. A Classical Defense of Reform in Liberal Education. Harvard: Harvard University Press. https://doi.org/10.2307/j. ctvjghth8

Nussbaum, M. (2002). Education for citizenship in an era of global connection. Studies in Philosophy and Education, 21(4-5), 289-303.

Osler, A. (2008). Citizenship education and the Ajegbo report: re-imagining a cosmopolitan nation. London Review of Education, 6(1), 11-25. https://doi.org/10.1080/1 4748460801889803

Ricoeur, P. (1984). L'idéologie et l'utopie: deux expressions de l'imaginaire social. Autres temps, 2(1), 53-64. https://doi.org/10.3406/chris.1984.940

Ricoeur, P. (1986). Lectures on ideology and utopia. New York: Columbia University Press.

Ricoeur, P. (1992). Oneself as another. Chicago: University of Chicago Press.

Rizvi, F. (2008). Epistemic virtues and cosmopolitan learning. Australian Educational Researcher, 35(1). Access on 13.11.2019 https://link.springer.com/content/ pdf/10.1007\%2FBF03216873.pdf https://doi.org/10.1007/BF03216873

Rizvi, F. (2009). Towards cosmopolitan learning. Discourse: Studies in the Cultural PoliticsofEducation,30(3),253-268.https://doi.org/10.1080/01596300903036863
Roth, K. (2007). Cosmopolitan Learning. In K. Roth, \& N. Burbules (Eds.), Changing notions of citizenship education in contemporary nation-states (Educational futures: Rethinking theory and practice). Rotterdam: Sense Publishers, 10-29. https://doi.org/ 10.1163/9789087903367_003

Steger, M. (2009). Political ideologies and social imaginaries in the global age. Global Justice: Theory Practice Rhetoric, 2, 1-17. https://doi.org/10.1093/acprof:oso/97 80199286942.003 .0001

Stein, S., \& Andreotti, V. D. O. (2016). Higher education and the modern/colonial global imaginary. Cultural Studies $\leftrightarrow$ Critical Methodologies, 17(3), 173-181.

Stein, S., Andreotti, V. D. O., \& Suša, R. (2016). 'Beyond 2015', within the modern/colonial global imaginary? Global development and higher education. Critical Studies in Education, 1-21. https://doi.org/10.1080/17508487.2016.1247737

Taylor, C. (2004). Modern social imaginaries. Durham, N.C.: Duke University Press. https://doi.org/10.1215/9780822385806

Todd, S. (2008). Toward an imperfect education: facing humanity, rethinking cosmopolitanism. Boulder, CO: Paradigm Publishers.

Welply, O. (2015). Re-imagining otherness: An exploration of the global imaginaries of children from immigrant backgrounds in primary schools in France and England. European Educational Research Journal, 14(5), 430-453. https://doi.org/1 $0.1177 \% 2$ F1474904115603733

Welply, O. (2019). A crisis in education? An Arendtian perspective on citizenship and belonging in France and England. British Journal of Sociology of Education, 40(6), 759-775. https://doi.org/10.1080/01425692.2019.1592661

\section{Oakleigh Welply, PhD}

is an Associate Professor at the School of Education, Durham University. She received her PhD in Sociology of Education from the University of Cambridge. Her main areas of research and teaching include social theory; the relationship of education to issues of language, religion, globalisation and citizenship; national policies of integration and youth identities; immigration and education in France and England; and global citizenship education. Theoretically, her work is mainly inspired by the works of Paul Ricoeur, Hannah Arendt and Pierre Bourdieu to investigate the intersection between wider structures and the subjectivities of young immigrants' identities and experiences. 